\title{
Construction of Logistics Management Specialty and of Development Evaluation Index System*
}

\author{
Shijun Yuan \\ Hunan Vocational College of Modern Logistics \\ Changsha, China 410131
}

\author{
Jianhua Chen** \\ Hunan Vocational College of Modern Logistics \\ Changsha, China 410131 \\ **Corresponding Author
}

\begin{abstract}
Based on the comprehensive analysis of the experience of logistics management major construction in Hunan Modern Logistics Vocational and Technical College, this paper puts forward the basic ideas for the construction of evaluation index system of logistics management specialty construction and adjustment, and provides reference for other colleges and universities.
\end{abstract}

Keywords-logistics management; specialty; evaluating indicator

\section{INTRODUCTION}

In 2014, the decision of the State Council on speeding up the development of modern vocational education put forward the "Expanding the establishment and adjustment of specialties in Vocational colleges... The autonomy of running a school" will give vocational colleges the autonomy to set up and adjust their specialties according to their own conditions of running a school and the demand of social employing units. This paper is based on the achievements of the demonstration specialty construction of logistics management in Hunan Province." Considering the actual situation of various schools and regions, this paper studies the "Self-evaluation Standard of Logistics Management Specialty in higher Vocational Education", which provides a reference for the relevant vocational colleges to set up and adjust their specialties.

\section{LITERATURE REVIEWED}

At the policy guidance level: the current higher vocational colleges in the establishment of logistics management major, General reference is made to the "Establishment Standard of higher Vocational School of the Ministry of Education (temporary)" and "Teaching Standard of Logistics Management in higher Vocational School", but these two standards have no clear provisions on the basic conditions of setting up a specific specialty.

On the research of professional setting standards, Wan Chunfen (2011) put forward the development process of professional setting standards on the basis of the analysis of German vocational education, Han Lulu (2010) proposed to develop professional setting standards from the perspective of

*The phased achievements of the Teaching and Research Project (JZW2016085) of Logistics Teaching Reform in National Colleges and Universities. social needs, Wu Xiaochen et al. (2013) developed the setting standards of food biotechnology specialty.

In the research of the related standards of logistics management major in higher vocational education: Li Hong (2010), Zhao Dan et al. (2012), Guan Tangchun (2013), Liu $\mathrm{Na}$ and others (2014) have mainly explored the curriculum construction and curriculum standard construction of logistics management major, and Tan Dexi et al (2012) from the perspective of teaching standards, Wang Cuimin et al. (2013) explored the quality standard of logistics management personnel training.

\section{ANALYSIS ON THE GOAL OF TALENT TRAINING}

\section{A. Related Policy}

The decision of the State Council on speeding up the development of modern vocational education puts forward that "specialized vocational colleges and universities should closely cooperate in production, education and research to train technical and skilled personnel who serve regional development". The aim of training talents of logistics management in higher vocational colleges should be to train the talents of logistics technical skills in regional development.

\section{B. Academic Theory Field}

Huang Huichun et al (2008) think that the specialty of logistics management in higher vocational colleges should train application-oriented specialized talents and adapt to the demand of social logistics talents and can serve the logistics fields such as warehousing, distribution, procurement, logistics planning and so on. Gou Jianhua (2008) thinks that it is necessary to train all kinds of applied talents of logistics technology application, logistics management and service in the first line of logistics and logistics enterprises in higher vocational logistics management specialty according to the actual work position of logistics department and logistics enterprise. Hu Fang (2009) believes that the logistics management major in higher vocational colleges should be based on the requirements of the enterprise' $\mathrm{s}$ actual position for the ability and quality. The aim is to train all kinds of applied talents of logistics management and service in the first line logistics technology of enterprise logistics and logistics enterprises. Chen Shiying (2010) put forward that the logistics talents trained in higher vocational colleges are complex 
talents with wide caliber, thick foundation, comprehensiveness and application. The theoretical knowledge of talent training is defined as the middle and primary level, and in the practical skill level, it should have the skills required by the national material flow teacher (including assistant material streamer) standard. Wu Xiaoyan (2010), starting from the development of regional industry and logistics in Shanghai, put forward three professional training objectives and curriculum system of "port logistics", "manufacturing logistics" and "urban distribution logistics".

\section{Brief Summary}

No matter the government or the experts, the implementation of colleges and Universities, the training goal of logistics management talents in higher vocational colleges is to foster the demand of high-quality logistics technical talents to promote the "regional industry and enterprise development"

\section{CONSTRUCTION EXPERIENCE OF HUNAN MODERN LOGISTICS VOCATIONAL AND TECHNICAL COLLEGE}

The logistics management specialty of Hunan Modern Vocational and Technical College, as a provincial key construction project of Hunan vocational education "12th FiveYear" in 2011, is a "demonstration specialty construction project", after three years of construction, it has successfully completed various indexes and achieved fruitful results. In the acceptance of the project, it is appraised as "excellent" Grade. The experience of "demonstration specialty of logistics management" is summarized as follows:

\section{A. Establishing a Long-term Mechanism for Cooperation Between Schools and Enterprises}

The four professional directions of the logistics management specialty cooperate with the local well-known logistics enterprises (logistics parks) in Hunan Modern Logistics Vocational Education Group, set up the third party logistics consulting planning team, Xiang Liu Technology Consulting Co., Ltd., and set up the corresponding Council. The Secretariat is set up at the Hunan Modern Vocational College of Logistics Management. The two level and three level institutions of the college have carried out their work, and by perfecting their institutions and perfecting the system, the school enterprise cooperation mechanism of "Talent co education, process co management, responsibility sharing, and results sharing" has been fully constructed.

\section{B. Innovative Talent Training Model}

The college has implemented a professional dynamic adjustment mechanism. According to the situation of professional research, the college has revised the talent training program every year, promote the "1323" (the docking of an industry, professional ability training as the center, taking into account the 3 levels of students' career development, the implementation of the "dual", "three teachers" training) high skilled logistics personnel training mode innovation and Practice, it has strengthened cooperation with many cooperative enterprises, optimized the training process of highend skilled talents in talent logistics, and formed a long-term mechanism for talent co education.

\section{Reconstructing the Modular Curriculum System Based on Business Process}

The college adheres to the guidance of vocational ability training, relies on Hunan Modern Logistics Vocational Education Group, strengthens cooperation with domestic firstclass and regional leading logistics enterprises, strengthens investigation and demonstration, and determines the professional post needs of industry enterprises, takes the core professional skills and the most advanced technologies as the main line, integrates professional knowledge, skills and qualities, selecting, determines and updates the teaching contents of the major key courses, strengthens the cultivation of the professional core vocational competence, reconstructing the modular course system based on business process of "professional basic competence, professional core competence and professional direction ability" with the characteristics of logistics specialty group.

\section{Quality Improvement Teaching Team}

With the national teaching team as the benchmark and the provincial teaching team of modern logistics specialty as the core, the college has built a teaching team of "academician guidance, famous teacher guidance, special and combined, international vision, high moral character" teaching team. We have trained 2 provincial professional leaders, 1 provincial excellent teachers and young backbone teachers, 2 professors, 10 doctors, 30 backbone teachers, and 100 percent of the fulltime teachers have participated in domestic training and enterprise practice, the "double teacher" teacher reached $100 \% .50 \%$ of the full-time teachers take part in foreign learning and academic exchanges, and employ senior management of the logistics industry with practical experience and a part-time teacher as a first-line engineering technician.

\section{E. Building the Training Base Group Inside and Outside the School}

The modern logistics training base includes the basic quality and skill training and testing room of logistics management specialty, the new training and verification training room of common equipment in logistics, the new training and testing room of logistics simulation platform, and the practical training room of Internet of things in time and application, supply chain logistics operation training center, three professional management ability training center, etc., set up 29 systematic internal supply chain logistics simulation and simulation training room, deepen the cooperation with "famous enterprises and famous parks", The production training bases for "School of enterprises" are 15, and the production training bases for "Enterprise of schools" are 3 . The college has initially built a combination of teaching, training, certification, production, research and development of "the combination of the five in one, the combination of virtual and real" inside and outside the school training base group.

\section{F. The Construction of Diversified Teaching Resources}

"School and enterprise co-construction, high-quality sharing", constructed "one platform, three resources subdatabase" high-quality digital logistics professional teaching resources database, built the educational information work 
management space, The application technology of Internet of things is applied to integrate the space and resource platform of the university city, to construct the "digital interactive classroom", to connect the relevant data of the training room with each other, and to meet the needs of teaching demand and technology development according to the continuous updating of teaching resources, real time updates every year.

\section{The CONSTRUCTION OF LOGISTICS MANAGEMENT}

SPECIALTY IN Higher VOCATIONAL COLLEGES AND THE CONSTRUCTION OF DEVELOPMENT SELF-EVALUATION SYSTEM

With the comprehensive consideration of the training goal of the professional logistics management professionals and the achievements of the demonstration specialty construction, the college is constructing the logistics management specialty in six main aspects, including the "guarantee mechanism", "training mode", "curriculum system", "teaching team", "training system", "teaching resources" and so on and adjust the key index system.

\section{CONCLUSION}

Although this paper has constructed the evaluation index system of the construction and development of logistics management major in higher vocational education, it is necessary for higher vocational colleges to grasp the principles of reference, consciousness and individuation in the specific construction of specialty and the dynamic adjustment of specialty.

TABLE I. CONSTRUCtion OF LOGISTICS MANAGEMENT SPECIALTy IN HighER VocATIONAL EdUCATION AND AdJUSTMENT OF KEy INDEX SySTEM

\begin{tabular}{|c|c|c|c|}
\hline \multirow[b]{2}{*}{$\begin{array}{l}\text { First Level } \\
\text { Index }\end{array}$} & \multirow[b]{2}{*}{ Second Level Index } & \multicolumn{2}{|c|}{ Professional Setup and Adjustment Requirements } \\
\hline & & Basic conditions for the establishment of specialty & $\begin{array}{c}\text { Three-year construction period (professional adjustment) } \\
\text { indicators }\end{array}$ \\
\hline \multirow{5}{*}{$\begin{array}{l}\text { Industry } \\
\text { docking }\end{array}$} & $\begin{array}{l}\text { Structural } \\
\text { establishment }\end{array}$ & $\begin{array}{l}\text { School enterprise Cooperation Organization of } \\
\text { professional setup, and the development of } \\
\text { substantive work }\end{array}$ & $\begin{array}{l}\text { There are new members to join each year, and more than } \\
\text { two professional seminars are held each year. }\end{array}$ \\
\hline & Co-operative enterprise & $\begin{array}{l}\text { There are no less than } 5 \text { enterprises in each } \\
\text { professional (orientation) school enterprise } \\
\text { cooperation, there are no less than } 1 \text { enterprises in } \\
\text { order to cultivate cooperative enterprises. }\end{array}$ & $\begin{array}{l}\text { There are no less than } 10 \text { cooperative enterprises in each } \\
\text { major (direction), There are no less than } 3 \text { enterprises in } \\
\text { order to cultivate cooperative enterprises. }\end{array}$ \\
\hline & Professional guidance & $\begin{array}{l}\text { Invites professional senior enterprise experts to } \\
\text { guide professional construction }\end{array}$ & $\begin{array}{l}\text { Senior enterprise experts guide professional construction } \\
\text { and give advice on promoting professional construction } \\
\text { every year. }\end{array}$ \\
\hline & $\begin{array}{l}\text { Professional } \\
\text { investigation }\end{array}$ & $\begin{array}{l}\text { It has a detailed and in-depth study of regional } \\
\text { industry and development, regional logistics } \\
\text { industry and development, and regional logistics } \\
\text { talents demand. }\end{array}$ & $\begin{array}{l}\text { Carried out the annual detailed and in-depth study of } \\
\text { regional industry and development, regional logistics } \\
\text { industry and development, regional logistics talent } \\
\text { demand. }\end{array}$ \\
\hline & Train objective & $\begin{array}{l}\text { According to the results of the survey to formulate } \\
\text { a clear talent training goals. }\end{array}$ & $\begin{array}{l}\text { According to the results of the annual research on talent } \\
\text { training goals for fine tuning. }\end{array}$ \\
\hline \multirow{5}{*}{$\begin{array}{l}\text { Cultivation } \\
\text { mode }\end{array}$} & Post standard & Establish clear standards for key positions & $\begin{array}{l}\text { Perfect post standard system of seamless connection with } \\
\text { industry and enterprise }\end{array}$ \\
\hline & Quality standard & $\begin{array}{l}\text { Establish clear quality Standards for personnel } \\
\text { training. }\end{array}$ & $\begin{array}{l}\text { The quality Standard of Talent cultivation Passes the } \\
\text { verification of Industry enterprises }\end{array}$ \\
\hline & procedural standard & Establish clear training process criteria & $\begin{array}{l}\text { The revision of the standard of talent cultivation process } \\
\text { involves the participation of experts from industrial } \\
\text { enterprises. }\end{array}$ \\
\hline & Inspection standards & $\begin{array}{l}\text { Establish clear test criteria for the training of } \\
\text { talents }\end{array}$ & $\begin{array}{l}\text { The examination standard of talents is adjusted according } \\
\text { to the changes in the demand for talents by enterprises in } \\
\text { the industry. }\end{array}$ \\
\hline & Management system & $\begin{array}{l}\text { To establish a comprehensive system for the } \\
\text { training of talents. }\end{array}$ & $\begin{array}{l}\text { Revise the relevant management system according to the } \\
\text { adjustment and change of training mode. }\end{array}$ \\
\hline \multirow{4}{*}{$\begin{array}{l}\text { Curriculum } \\
\text { system }\end{array}$} & Curriculum standard & Establish a clear curriculum standard. & $\begin{array}{l}\text { The annual curriculum standards revised by experts from } \\
\text { industries and enterprises are deeply involved. }\end{array}$ \\
\hline & Teaching standard & Establish a clear teaching standard. & $\begin{array}{l}\text { The annual teaching standards revised by experts from } \\
\text { industries and enterprises are deeply involved. }\end{array}$ \\
\hline & $\begin{array}{l}\text { Curriculum } \\
\text { development }\end{array}$ & $\begin{array}{lcc}\text { Implement curriculum } & \text { development with } \\
\text { cooperative enterprises. } & & \\
\end{array}$ & $\begin{array}{l}\text { The curriculum development of industry enterprise } \\
\text { experts' Deep Participation, remarkable results. }\end{array}$ \\
\hline & Curriculum reform & $\begin{array}{l}\text { Carry out curriculum reform based on Regional } \\
\text { Industry and Enterprise Logistics needs. }\end{array}$ & $\begin{array}{l}\text { The course Reform practice of "Regional Industry and } \\
\text { Enterprise Logistics Demand" in the year, remarkable } \\
\text { results. }\end{array}$ \\
\hline \multirow{3}{*}{$\begin{array}{l}\text { Teaching } \\
\text { team }\end{array}$} & Professional leader & $\begin{array}{l}\text { Each professional (direction) has one professional } \\
\text { leader in schools and industries. }\end{array}$ & $\begin{array}{l}\text { Every year, professional leaders make substantial } \\
\text { contributions to professional construction and promote } \\
\text { the development of professional construction. }\end{array}$ \\
\hline & Exchange of learning & $\begin{array}{l}30 \text { percent of full-time and part-time teachers have } \\
\text { gained the experience of annual dispatching to } \\
\text { improve their teaching ability and quality. }\end{array}$ & $\begin{array}{l}\text { Within } 3 \text { years, all full-time and part-time teachers have } \\
\text { been given at least one chance to improve their teaching } \\
\text { ability and quality, remarkable results. }\end{array}$ \\
\hline & Enterprise top job & $\begin{array}{l}30 \% \text { of the full-time teachers already have the } \\
\text { practical teaching ability and quality of the } \\
\text { enterprise top job training experience. }\end{array}$ & $\begin{array}{l}\text { Within } 3 \text { years, all full-time and part-time teachers have } \\
\text { obtained at least one opportunity to learn and exchange } \\
\text { training to improve their teaching ability and quality, } \\
\text { remarkable results. }\end{array}$ \\
\hline
\end{tabular}




\begin{tabular}{|c|c|c|c|}
\hline \multirow{2}{*}{$\begin{array}{l}\text { First Level } \\
\text { Index }\end{array}$} & \multirow{2}{*}{ Second Level Index } & \multicolumn{2}{|c|}{ Professional Setup and Adjustment Requirements } \\
\hline & & Basic conditions for the establishment of specialty & $\begin{array}{c}\text { Three-year construction period (professional adjustment) } \\
\text { indicators }\end{array}$ \\
\hline $\begin{array}{l}\text { Teaching } \\
\text { team }\end{array}$ & $\begin{array}{l}\text { Teaching and research } \\
\text { reform }\end{array}$ & $\begin{array}{l}20 \% \text { of all-time teachers have the results of } \\
\text { teaching and research reform in their major or } \\
\text { related major. }\end{array}$ & $\begin{array}{l}\text { The professional teaching and research reform has been } \\
\text { actively carried out, within three years, teachers at all } \\
\text { levels have achieved no less than one per capita teaching } \\
\text { and research reform, of which no less than one per year } \\
\text { has been achieved at the provincial level. }\end{array}$ \\
\hline \multirow{3}{*}{$\begin{array}{l}\text { Practice } \\
\text { training } \\
\text { system }\end{array}$} & $\begin{array}{l}\text { Practice } \\
\text { standard }\end{array}$ & $\begin{array}{l}\text { The school-enterprise cooperation system designs } \\
\text { and implements the practice teaching system, } \\
\text { formulates the practice training safety operation } \\
\text { standard, the specialized post work standard and so } \\
\text { on practical training norms, the standard. The hours } \\
\text { of practical training are not less than } 40 \% \text { of the } \\
\text { total hours. }\end{array}$ & $\begin{array}{l}\text { According to the development trend of industry and } \\
\text { enterprise, school enterprise cooperation to amend the } \\
\text { practice teaching system and related norms and standards, } \\
\text { and the effect is remarkable. }\end{array}$ \\
\hline & Campus base & $\begin{array}{l}\text { Construction of real, simulation project classroom, } \\
\text { field classroom, etc., to meet the practical training } \\
\text { of students' professional courses on campus. }\end{array}$ & $\begin{array}{l}\text { Each specialty (direction) has built more than } 1 \text { intra } \\
\text { school productive practice training bases, to meet the } \\
\text { productive training demand of professional students on } \\
\text { campus. }\end{array}$ \\
\hline & Out of campus base & $\begin{array}{l}\text { Each major (direction) to build no less than } 1 \text { off- } \\
\text { campus training base to meet the top job practical } \\
\text { training needs of professional students. }\end{array}$ & $\begin{array}{l}\text { Set up a perfect system of productive training outside } \\
\text { school, the practical training time of off-campus practical } \\
\text { training base is not less than } 30 \% \text { of that of general } \\
\text { training. }\end{array}$ \\
\hline \multirow{2}{*}{$\begin{array}{l}\text { Instructional } \\
\text { resource }\end{array}$} & Curriculum resources & $\begin{array}{l}\text { All kinds of teaching resources are available to } \\
\text { meet the needs of curriculum teaching. }\end{array}$ & $\begin{array}{l}\text { The curriculum teaching resources are updated according } \\
\text { to the development trend of the industry, and the annual } \\
\text { update rate is not less than } 10 \% \text {. }\end{array}$ \\
\hline & Digital resources & $\begin{array}{l}\text { Building a sharing platform for teaching resources } \\
\text { in school, the core professional curriculum } \\
\text { resources digitization. }\end{array}$ & $\begin{array}{l}\text { Construct the sharing platform of teaching resources, } \\
\text { digitize professional curriculum resources and productive } \\
\text { practical training resources outside school. }\end{array}$ \\
\hline
\end{tabular}

\section{REFERENCES}

[1] Cui Yaqiong. Discussion on quality standard and evaluation of curriculum reform of logistics management specialty in Higher Vocational Education [J]. New west, 2012.17 phase.

[2] Liu Na et al. Construction of teaching content and curriculum system of Higher Vocational Logistics Management Specialty in line with industry standards [J]. Chinese market, 35 phase, 2014.

[3] Guan Tangchun. Development and Construction of Core Curriculum Standards for Logistics Management Major in higher Vocational Colleges [J]. Journal of Changsha Railway Institute (Social Sciences Edition), 2013(3).

[4] Jin Huan, etc. Application research on training and evaluation standard of main skill items in logistics Management major.[J]. Logistics engineering and management, Issue 7, 2010.

[5] Yuan Shijun. Summary of Research on setting Standards of Logistics Management Specialty in higher Vocational Colleges [J]. Market conditions.2014.11. 